\title{
The Effect of Brand Image and Social Media on Customer Retention through Customer Satisfaction at Kaliwatu Adventure
}

\author{
Mukhlas Rofiq \\ Student of Magister Tourism \\ Management University of Merdeka \\ Malang \\ Malang, Indonesia
}

\author{
Achmad Firdi \\ Magister Management \\ University of Merdeka Malang \\ Malang, Indonesia
}

\author{
Harianto Respati \\ Magister Management \\ University of Merdeka Malang \\ Malang, Indonesia
}

\begin{abstract}
This study aims to determine the effect of brand image and social media on customer satisfaction related to customer retention in the adventure tourism destination, Kaliwatu Adventure. This study uses primary data from the results of a questionnaire filled in by 100 respondents, i.e. rafting visitors at Kaliwatu Adventure. Brand image and social media influence customer retention through customer satisfaction, which means that customer satisfaction as mediation can increase the effect of brand image and social media on customer retention at Kaliwatu Adventure. This research proves that in the field of adventure tourism, brand image and social media directly influence customer retention.
\end{abstract}

Keywords:- Adventure Tourism, Brand Image, Customer Retention, Customer Satisfaction, Kaliwatu, Rafting, Social Media, Tourism.

\section{INTRODUCTION}

Tourism is a sector showing high growth every year (Ryglova et al., 2015). Tourism across the world experienced a growth of 5\% in 2018 and reached USD 1.4 billion (UNWTO, 2019). Tourism plays an important role in Indonesia's economic growth. It is determined as a leading sector in the 2015-2019 National Medium-Term Development Plan (RPJMN). Tourism is one of the biggest foreign exchange earners in Indonesia as generated by tourists spending and one of the effective factors in developing international retribution (Marpaung, 2002).

East Java, which is located between two provinces with great tourism potential, namely Central Java and Bali, flanked by the Java Sea and Indian Ocean has an advantage with its strategic position and easy access from other places. One of the cities with tourism potential in East Java is Batu City. Bearing the title as "Tourism City", Batu City Government plans to improve its position and role to become a "Tourism Center" supported by Batu City Regional Regulation No. 7/2011 Article 7b on Spatial Planning for Batu City Region in 2010-2030. The Batu City Regional Regulation indicates that tourism in Batu City has grown as supported with the policies (Hanas et al., 2014).
Tourism activists in Batu City do various ways to do marketing so that their products are well known by consumers, one of which is utilizing electronic media, which in the era of the industrial revolution 4.0 is currently developing very rapidly. Social media is an online media where users can easily access (participate, share, create content) the relevant platform (Nasrullah, 2017). As the number of social network users grow, the company is required to strengthen their existence through social media as a form of promotion. This certainly can affect the company's brand image because the users make the social media platform as the first assessment in product purchases.

Brand image is an assessment of consumers of the brand in a market. The creation of a brand image is obtained from personal experience or the reputation of the product told by other people or the media (Aaker and Biel, 1993). Imaging a brand in such a way will affect the desire of consumers to come or buy the products offered. The company's brand image is a company promise given to consumers that affects customer satisfaction (Yazid, 2003). Customer satisfaction is an important thing that must be maintained by the company. It represents the expected performances of a product felt by the buyers. The combination of customer satisfaction obtained to the service excellence provided will trigger customer retention (Kotler et al., 2001). Customer retention is a tendency of customers to continue to insist on using products or services in the future (Sari and Suryadi, 2016).

For companies, customer retention provides an opportunity to obtain greater profits because the company does not need to pay more for product introduction. The influence of brand image and social media to customer satisfaction and customer retention needs to be investigated to find out the effects caused in a tourist destination, e.g. an adventure tourism destination. Kaliwatu Adventure is a training and development center for human resources engaged in adventure tourism-based services using an outdoor activity approach. Kaliwatu is an adventure tourism company with experiential learning-based media. The company has a vision to be a market leader in tourism services with international standards and beneficial for the homeland, nation, and religion. Kaliwatu is one of the rafting tour providers in Batu City that puts safety, comfort, and customer satisfaction in their rafting experiences. 


\section{LITERATURE REVIEW}

\section{A. Brand Image}

Brand is associated with the name or design or a combination of both that is intended to identify products from manufacturers that will distinguish them from their competitors (Kotler, 1994). Brand image is the consumer's assessment of the brand. The creation of a brand image is based on personal experience or the reputation of the product told by other people or the media (Aaker and Biel, 1993).

\section{B. Social Media}

Social media is an online media where users can access (share, participate, create) the relevant platform (Nasrullah, 2017). Internet-based applications allow the creation and exchange of user-generated content. Social media is built based on Web 2.0 technology (Haenlein, 2010).

\section{Customer Satisfaction}

Customer satisfaction is an important thing that must be maintained by the company. Consumer satisfaction on a product can meet the expectations of consumers (Kotler et al., 2001). Satisfaction directs customers toward a longterm beneficial relationship with a brand and gives value to the brand by expanding word of mouth marketing that builds brand reputation (Hanif et al., 2010).

\section{Customer Retention}

Customer retention is a strategy that aims to build a good relationship between the company and its customers focusing on creating loyal customers by influencing consumers to be willing to buy products on an ongoing basis (Santoso et al., 2018).

\section{METHODOLOGY}

This study used qualitative design with four research hypotheses namely:

H1: $\quad$ Brand image and social media have a significant effect on customer satisfaction at Kaliwatu Adventure.

$\mathrm{H} 2$ : $\quad$ Brand image and social media have a significant effect on customer retention at Kaliwatu Adventure.

H3: Customer satisfaction has a significant effect on customer retention at Kaliwatu Adventure.

H4: Brand image and social media have a significant effect on customer retention through customer satisfaction at Kaliwatu Adventure.

Description analysis was used to explain the description of each variable studied, while multiple linear regression analysis were used to determine the effect of the variables tested. Primary data collection used a questionnaire with five answer choices of Likert scale that can be chosen by respondents.

\section{Population and Sample}

This study used primary data obtained from interview based on a list of questions to a number of respondents selected for this study. Research respondents were rafting visitors at Kaliwatu Adventure. The sample collection method used is the Slovin method determined with the following formula:

$$
n=\frac{N}{1+\mathrm{N} e^{2}}
$$

Where $\mathrm{n}$ is the minimum sample number, $\mathrm{N}$ is the population number, while e is the error margin. Slovin method was used to determine the sample by considering an error rate of 5\%, so that the sample size of 100 respondents from a population of 1000 visitors was obtained. The sampling technique used simple random sampling technique with the consideration that each visitor has the same opportunity to answer the research questionnaire.

\section{$>$ Analysis Methods}

The analytical method used is structural equation modeling, i.e. a combination of factor analysis, regression, and path analysis. In this model, testing can be done to determine the value of direct, indirect, and total influence between exogenous and endogenous variables.

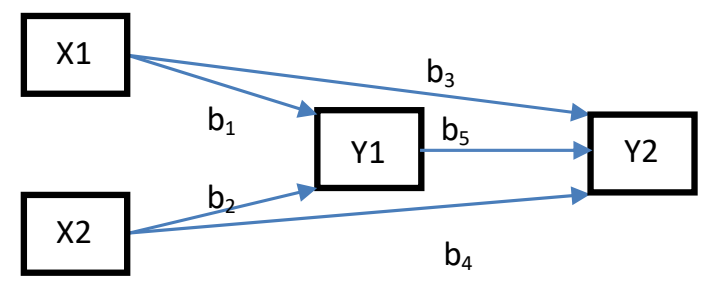

Fig 1:- Structure Equation Model (SEM) Source: Processed Data (2020)

\section{RESULT AND DISCUSSION}

All items had $r$ values greater than $r$ tables and the probability was smaller than $\alpha=5 \%$, meaning that there was a significant relationship between the scores of each indicator with the total score. This shows that the indicator can be used to measure the variable to be measured; on other words, the instrument was valid.

\begin{tabular}{|c|c|}
\hline Variable & Reliability \\
\hline Brand Image (X1) & 0.820 (good reliability) \\
\hline Social Media (X2) & 0.857 (good reliability) \\
\hline Customer Satisfaction (Y1) & 0.871 (good reliability) \\
\hline Customer Retention (Y2) & 0.808 (good reliability) \\
\hline
\end{tabular}

Table 1:- Instrument Realibilty

Source: Processed Data (2020) 
Table 1 shows the results of data processing for the reliability analysis. It can be concluded that the existing questionnaire items in all variables had a good reliability coefficient, meaning that the respondents were consistent in expressing the answers to the questionnaire.

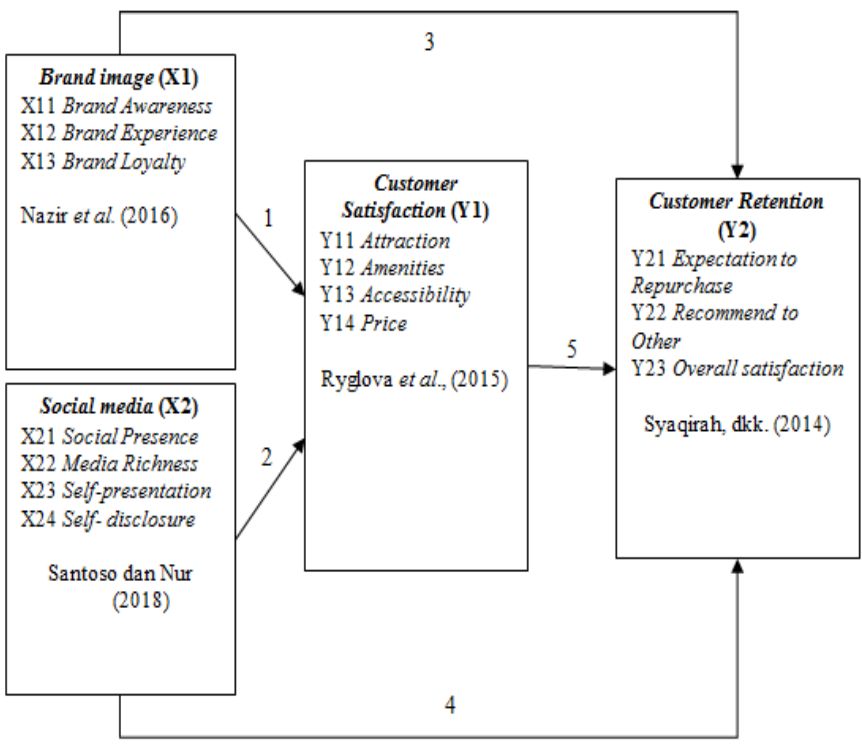

Fig 2:- Research Conceptual Model Source: Processed Data (2020)

\section{A. Description of Variables}

Brand image is formed by brand awareness, brand experiences, and brand loyalty. The main thing that drives brand image is that brand experience reflected in the respondents' agreement regarding the competence of a trusted facilitator. Brand experience is a type of experience based on marketing that combines a series of holistic conditions created by a company to influence the feelings that customers have about a product or a particular company name (Coleman, 2018). The visitors' knowledge about the competency of the facilitator as a brand experience is one of the effective tools to evaluate how willing the customer is to have rafting experience at Kaliwatu Adventure.

Social media is formed by self-presence, media richness, self-presentation, and self-disclosure. Selfpresence indicator is the main forming indicator of social media because it is a representation of customer and company communication. Customer communication to Kaliwatu Adventure can be easier as there is Instagram social media platform used as a communication bridge that speeds up Kaliwatu Adventure's response and improves company services. Self-disclosure forms social media, as well. Social media is a means used to express what the customers feel about the experience at Kaliwatu Adventure. The customers can upload their experiences through feeds and stories on Instagram. Krishna, et al. (2011) stated that social media has an appeal to customer satisfaction because it provides an opportunity for customers to communicate faster to the company and allows the company to respond more quickly to customer complaints and thus can improve the company's service to customers.
Customer satisfaction is formed by attraction, amenities, accessibility, and price. In this study, amenity increased customer satisfaction since there is a special shuttle to mobilize customers who do rafting at Kaliwatu Adventure. Customers were satisfied with the facilities and services provided by Kaliwatu Adventure through the existence of a shuttle facility that facilitates customer access for rafting. The services provided also take part in determining customer satisfaction, especially when using the shuttle during the trip from the Kaliwatu basecamp to the rafting starting point and pickup from the finish point to the Kaliwatu basecamp. Ryglova et al. (2015) stated that a destination has 5 main components that must be met, one of which is amenities. If the component is fulfilled, it will improve the quality of the destination and be able to measure the quality of the destination. Furthermore, Bolton and Ruth (1998) stated that customer satisfaction in general is an impression of customers regarding product quality, service quality, and price.

\section{B. Brand Image, Social Media and Customer Satisfaction}

Brand Image has no effect on customer satisfaction, so brand image does not cause an increase or decrease in the level of visitor satisfaction at Kaliwatu Adventure. Some things that have the probability of causing this are that visitors prioritize quality on site compared to the initial expectations that were built before having activities at Kaliwatu Adventure. There was also another factor such as respondents who had the first time participating there. Thus, they had no clues about the Kaliwatu brand image. This is consistent with Harianto's research (2013) which shows that brand image has no significant effect on customer satisfaction. A good image owned by a brand is not a guarantee of customer satisfaction.

Indicators in brand image include brand awareness, brand experiences, and brand loyalty. The indicator which had the biggest contribution in this study was brand experiences determined from visitors' personal experiences for the services provided. The biggest influential contribution is the competency of the facilitator. Brand image determines the consumer's decision to buy the product but it has no effect on customer satisfaction. Tyas and Andreas (2017) found that the combination of brand image and service excellence influences customer satisfaction. In this study, it can be concluded that the brand image factor was not able to provide customer satisfaction, so it is necessary to strive for service excellence. How visitors feel when they make contact with the brand provides experiences that shape the brand image in the visitors' mind. Brand image cannot directly influence visitor satisfaction because satisfaction tends to be fulfilled when someone tries product performance so that it can be used as a basis for assessment. This is in line with Kotler et al. (2001) stating that brand identity is defined as how a company describes itself to customers. Brand image, on the other hand, can be defined as how customers really understand the brand. Companies lack control over brand image and always try to align it with brand identity. The same thing is done by Kaliwatu, as a company based on learning, adventure and tourism, they always ensure that the 
quality of service is always excellent and including facilitators who have competency standard certification. Therefore, the visitors do not only assess the brand image, but also feel the experiences.

Social media has an effect on customer satisfaction. Thus, the use of social media can increase customer satisfaction. Kaliwatu uses social media as a means of wider interaction with consumers. Easy and fast access provides an opportunity for Kaliwatu to expand interactions to share information related to promotions and other marketing strategies quickly to the consumers. This is in line with Fajri and Jasma (2018), stating that the implementation of effective marketing programs on social media can enable organizations to create beneficial relationships with their consumers while increasing satisfaction.

Social media indicators include social presence, media richness, and self-presentation. The biggest contribution to customer satisfaction is the social presence, which is a function of social media as a communicative representation of the company. This is in line with Haenlein (2010), stating that social media is seen as an online facilitator that strengthens the relationship between users as well as a social bond. As a form of representation and a place for communication, Kaliwatu's online marketing team always do the maintenance so that interactive communication with consumers can be well established. Social media, like Instagram, has a big role, where the feeds (in the form of images and videos) uploaded can be a means of communication. Through infographics, consumers can absorb information better so that things related to the promotion to be conveyed are more easily accepted. Social media is one of the communication media used at Kaliwatu in which the customers can interact directly with the Kaliwatu team without the constraints of time and location. This leads to consumers satisfaction because more opportunities to meet their needs, especially the ease of obtaining information.

\section{Brand Image, Social Media and Customer Retention}

Brand image affects customer retention. The better the brand image in the eyes of visitors, the more likely the visitors make a return visit. The more positive a brand image will have a higher purchase impact on products from the brand (Setiadi, 2003). A good brand image makes a good brand perception in the minds of customers. These perceptions can develop over time. Customers form a picture based on their interactions and experiences of using the brand. This interaction takes many forms and does not always involve the purchase or use of products and services.

Indicators in brand image include brand awareness, brand experiences, and brand loyalty. The indicator with the biggest contribution is brand experiences, where this indicator is determined from visitors' personal experiences for the services provided. Sahin et al. (2011) stated that brand experiences are conceptualized as sensations, feelings, cognitions, and behavioral responses arising from brand-related stimuli that are part of the design and identity, packaging, communication, and brand environment. The biggest contribution that influences this indicator is the competency of the facilitator. A brand can be felt differently by different customers; therefore, the formation of a consistent brand image is an important task for the company, in this case, Kaliwatu is no exception. Kaliwatu brand image which is continuously considered good will bring up the desire of consumers to return to enjoy the products offered. In addition, the success of customer retention can also be interpreted when visitors bring and invite new guests to visit Kaliwatu because they were previously satisfied with the brand image.

Social media influences customer retention. Through social media, consumers get information about developments made by Kaliwatu. Customer satisfaction is the extent to which the assumption of product performance meets the expectations of buyers (Kotler et al., 2001). Social media is one of the factors that shape visitors' expectations for a product. The use of social media can increase visitor expectations on product performance. Kaliwatu's task as a good activity provider is to provide excellent service that is in line with or even exceeds the expectations of visitors. The combination of customer satisfaction obtained to the service excellence provided will trigger customer retention.

Social media indicators include social presence, media richness, and self-presentation. The biggest contribution to customer satisfaction is the social presence. The existence of social media provides additional communication channels. If social media is integrated with other channels, companies will more easily spread the benefits of added value such as loyalty schemes and customer clubs (Stokinger and Wilson, 2014). Consumers who have visited Kaliwatu and followed their official social media accounts will get the latest updates related to products, locations, promotions, etc. Regular updates are needed to maintain the existence of the product; because through social media, visitors know new things that have the potential to be enjoyed when visiting Kaliwatu.

\section{Customer Satisfaction and Customer Retention}

Customer satisfaction affects customer retention, meaning that the higher level of customer satisfaction can increase customer retention. The main indicator that increases customer satisfaction is amenities due to the existence of a special shuttle for the mobilization of customers who do white water rafting at Kaliwatu Adventure. Customers are satisfied with the facilities and services provided by Kaliwatu Adventure through the existence of a shuttle facility that facilitates customer access for rafting. Ryglova et al. (2015) stated that a destination has 5 main components that must be met, one of which is amenity. If the component is fulfilled, it will improve the quality of the destination and be able to measure the quality of the destination. Customer satisfaction is the impression of customers regarding product quality, service quality, and price (Boltond and Ruth, 1998). 


\section{E. The Role of Customer Satisfaction}

Customer satisfaction serves as a mediator of the influence of brand image and social media on customer retention. This shows that brand image and social media can improve customer retention if it is supported by customer satisfaction from Kaliwatu Adventure customers. Brand image has a weak influence on customer satisfaction, but it has a direct influence on customer retention. Thus, with customer satisfaction, brand image has an indirect effect that supports customer retention from customers. This is consistent with the research that has been presented by Nazir et al. (2016), stating that brand image has 3 components that influence customer retention with customer satisfaction as a medium, namely brand awareness, brand experience, and brand loyalty. Customer satisfaction also indirectly increases the influence of social media. This is in line with Krishna et al. (2011), stating that social media has an appeal to customer satisfaction because it provides an opportunity for customers to communicate faster with the company, allow the company to respond more quickly to customer complaints, improve company service to customers.

\section{CONCLUSION}

From the results and discussion, it can be concluded that:

$>$ Brand Image has no effect on customer satisfaction. Thus, brand image does not cause an increase or decrease in the level of visitor satisfaction at Kaliwatu. Some things that have a probability of causing this are that visitors prioritize quality on site compared to the initial expectations that were built before having activities at Kaliwatu. There was also another factor such as respondents who were still had the first time participating in activities there. Thus, they had no clues about so as not to have a view of the Kaliwatu brand image Social media has an effect on customer satisfaction; so that the use of social media can increase customer satisfaction.

$>$ Brand image influences customer retention. The better the brand image in the eyes of visitors, the more likely the visitors make a return visit. A good brand image makes a good brand perception in the customers' mind. These perceptions or images can develop over time. Social media influences customer retention. Through social media, costumer easily get information about developments made by Kaliwatu.

$>$ Customer satisfaction affects customer retention, meaning that the level of customer satisfaction can increase customer retention of rafting customers at Kaliwatu Adventure.

$>$ Brand image and social media influence customer retention through customer satisfaction, meaning that customer retention as mediation can increase the influence of brand image and social media on rafting customer retention at Kaliwatu Adventure.
From these conclusions, it is recommended for Kaliwatu to continue to make continuous improvements in building brand image and social media. A good brand image in the eyes of the community will provide a positive resonance for the company. Through positioning, brand value, and the right concept, companies need to make a combination of various strategic steps to increase visitor trust in the brand image and social media of Kaliwatu Adventure so that there is an increase in customer retention. Providing innovations and creations that are always needed by visitors, so that entrepreneurial marketing to market the products, exist, and meet the costumers' demand.

\section{REFERENCES}

[1]. Aaker and Biel. (1993). Brand Equity and Advertising: Advertising's Role in Building Strong Brand.

[2]. Anderson, E.W., and Sullivan M.W. (1993). The Antecedents and Consequences of Customer Satisfaction for Firms. Marketing Science 12(2), pp. 125-143.

[3]. Bolton, Ruth N. (1998), "A Dynamic Model of the Duration of theCustomer's Relationship with a Continuous Service Provider:The Role of Satisfaction," Marketing Science, 17 (Winter),45-65.

[4]. Coleman, D. (2018). Building Brand Experiences: A Practical Guide to Retaining Brand Relevance. London.

[5]. Fajri, D., dan Jasma J.M. (2018). Pengaruh Social Media Marketing dan Promosi Harga Terhadap Kepuasan Konsumen dan Pengalaman Konsumen Sebagai Variabel Mediasi Pada Maskapai Penerbangan Airasia di Banda Aceh. Jurnal Ilmiah Mahasiswa Ekonomi Manajemen 3(3): 33-48.

[6]. Haenlein, M. (2010). Users of the world, unite! The challenges and opportunities of Social Media. New York: Business Horizons.

[7]. Hanas, Imron., Sasmita, Nurhadi (2014). Mengembangkan Pariwisata Membangun Kota: Kota Batu, 2001-2012, Artikel ilmiah Mahasiswa 2014. Fakultas Sastra, Universitas Jember.

[8]. Hanif, M.,Hafeez, S. and A. Riaz, 2010. Factors Affecting Customer Satisfaction. International Research Journal of Finance and Economics 60: 44-52.

[9]. Harianto, D. (2013). Analisa Pengaruh Kualitas Layanan, Brand Image, dan Atmosfer terhadap Loyalitas Konsumen dengan Kepuasan Konsumen sebagai Variabel Intervening Konsumen Kedai Deja-vu Surabaya. Jurnal Strategi Pemasaran 1(1): 1-8

[10]. Hidayatullah, S., Rachmawati, I. K., Aristanto, E., Waris, A., \& Patalo, R. G. (2020). Peran Sistem Informasi Pemasaran, Kualitas Pelayanan dan Entrepreneurial marketing serta Kepuasan Terhadap Loyalitas Generasi Milenial Berkunjung ke Tempat Wisata. https://doi.org/10.32812/jibeka.v14i1.148

[11]. Kotler, P (terj). (1994). Manajemen Pemasaran: Analisis. Perencanaan, Implementasi, dan Kontrol. Jilid 1. Edisi Kesembilan. Jakarta: Prenhalindo.

[12]. Kotler, Philip and Gary Amstrong. (terj). (2001). Dasar-Dasar Pemasaran. Jilid 1. Jakarta: Prenhalindo. 
[13]. Krishna, A., Dangayach, G., and Jain, R. (2011). A Conceptual Framework for the Service Recovery Paradox. The Marketing Review, 11(1), 41-56. Doi:10.1362/146934711X565288.

[14]. Marpaung. (2002). Pengetahuan Kepariwisataan. Bandung: Alfabeta.

[15]. Nasrullah R. (2017). Media Sosial: Perspektif Komunikasi, Budaya, dan Sosioteknologi. Bandung: Remaja Rosdakarya.

[16]. Nazir, Bina, Ali, Muhammad, Jamil, Mehwis (2016). The Impact of Brand Image on the Customer Retention: A Mediating Role of Customer Satisfaction in Pakistan, International Journal of Business and Management Invention Vol5 No 3: March 2016.

[17]. Ranaweera, C, and Prabhu. (2003). J, The influence of satisfaction, trust and switching barriers on customer retention in a continuous purchasing setting, International Journal of Service Industry Management, vol,14, no,4, pp, 374-395, http://dx.doi.org/10,1108/09564230310489231, 2003.

[18]. Ryglova, Katerina., Vajcnerova, Ida., Sacha, Jakub., Stojarova, Sarka. (2015) The Quality as a Competitive Factor of The Destination, Business economic and management 2015 conference, BEM 2015, Vol 34, pp 550556

[19]. Sahin, A., Cemal Z., and Hakan K. (2011). T he Effects of Brand Experiences, Trust and Satisfaction on Building Brand Loyalty; An Empirical Research On Global Brands. Procedia - Social and Behavioral Sciences 24:1288-1301. DOI: 10.1016/j.sbspro.2011.09.143

[20]. Santoso, Radityo Kusumo dan Dewi, Nur Fadilah (2018) The influence of Social Media Against Customer Retention (Case Study on J.Co). The 2nd International Conference on Vocational Higher Education (ICVHE) 2017

[21]. Sari, D.H., and Suryadi, N. (2016). Pengaruh Kepuasan Pelanggan dan Switching Barrier terhadap Customer Retention Kartu GSM (Studi Kasus Pada Mahasiswa Universitas Brawijaya Malang). Jurnal Ilmiah Mahasiswa FEB 1(2): 1-14

[22]. Setiadi, J. Nugroho (2003). Perilaku Konsumen: Konsep dan Implikasi untuk Strategi dan Penelitian Pemasaran. Jakarta: Prenada Media.

[23]. Stokinger, E., and Wilson O. (2014). Social Media and Customer Retention: Implications for the Luxury Beauty Industry. IGI Global. London.

[24]. UNWTO (2019). International Tourism Highlights International tourism continues to outpace the global economy, pp. 1-24. doi: https://www.eunwto.org/doi/pdf/10.18111/9789284421152?downlo ad=true.

[25]. Yazid. (2003). Pemasaran Jasa. Yogyakarta: Ekononisia. 